\title{
POSSIBLE CONSEQUENCES OF DECLARING CIVIL AND CUSTOMARY MARRIAGES VOID
}

\section{Introduction}

The consequences of declaring a civil marriage entered into during the existence of a customary marriage or vice versa void could have nowhere been fully canvassed. On the face of it, it merely calls for a declaration of invalidity of the existing marriage, but it raises various ancillary issues which have not been addressed. We do not discuss the judgments declaring marriages void, but focus on the consequences of such judgments.

For a variety of reasons it is important to determine whether a civil marriage, concluded subsequent to a customary marriage, is valid or $a b$ initio void, or vice versa.

To mention but one reason:

"Where immovable property, a real right in immovable property, a bond or a notarial bond -

(d) is registered in the name of a person who on the date of the registration was a party to a marriage governed by the Recognition of Customary Marriages Act, 1998 (Act 120 of 1998)

the registrar shall on the written application by the person concerned and on the submission of the deed in question and of proof of the relevant facts, endorse the change in status or make a note of the effect that the said person

is a party to a marriage in community of property, as the case may be" (S

17(4) of the Deeds Registries Act 47 of 1937).

When a marriage is void, no consequences flow from it, except in so far as it may be deemed to be a putative marriage.

Lawyers, officials and the public at large still do not seem to realize that in terms of sections 2(1) and (2) of the Recognition of Customary Marriage Act (120 of 1998) customary marriages entered into before and after commencement of the Act are for all purposes recognized as marriages.

The case of Netshituka $v$ Netshituka (426/10 [2011] ZACSA 120 dated 2011-07-20) has now given clear direction as to the validity or non-validity of civil marriages concluded after the Marriage and Matrimonial Property Law Amendment Act 3 of 1988.

Also in Thembisile $v$ Thembisile (2002 (2) SA 209 (T) par 32) Bertelsmann $\mathrm{J}$ held that a civil marriage contracted while the man was a partner in an existing customary marriage with another woman was void.

The position of the validity of civil marriages, entered into prior to and after the said Amendment Act, will now be discussed. 


\section{Brief survey}

\section{Position before 1 December 1988}

Spouses in a customary union were, prior to the Recognition of Customary Marriages Act (120 of 1998) not regarded as legally married to each other. A spouse could thus, at any time during the subsistence of such marriage, conclude a valid civil marriage with another person. The effect of such civil marriage on the customary union, was that such union was automatically dissolved (Nkambula v Linda 1951 (1) SA 377 (A); and Malaza v Mndaweni 1974 BAC (C) 45). The wife to such customary union was known as a discarded spouse. The wife to such union could also contract a civil marriage with another person, and similarly the existing union was automatically dissolved.

\section{Position from 2 December 1988}

In terms of the Marriage and Matrimonial Property Law Amendment Act 3 of 1988, which came into operation on 2 December 1988, the Black Administration Act 38 of 1927 was amended and it had the following consequences:

- All civil marriages in South Africa were put on par with one another, and the Matrimonial Property Act (88 of 1984) was also made applicable to Black marriages concluded with effect from 2 December 1988. Marriages thus concluded from 2 December 1988 were automatically in community of property, unless an antenuptial contract was entered into and registered within three months of conclusion thereof in the deeds registry.

- Another important innovation was that the customary union was not automatically dissolved by the civil marriage. The amended section 22(1) of the Black Administration Act (38 of 1927) prohibited a husband of a customary marriage from contracting a civil marriage with another woman during the subsistence of such customary marriage.

\section{Position from 15 November 2000}

Section 3(2) of the Recognition of Customary Marriages Act (120 of 1998) now also prohibits a spouse, who is a party to a valid customary marriage, from entering into a civil marriage in terms of the Marriage Act (25 of 1961). This provision has merely confirmed the repealed section 22(1) of the Black Administration Act.

From the above it is clear that the date of conclusion of the civil marriage will be the deciding factor to ascertain whether such marriage is valid where the husband had entered into a prior customary marriage.

Where the civil marriage was concluded after 2 December 1988 and there existed a customary marriage, irrespective of whether the customary marriage was registered or not, the civil marriage is a nullity and the customary marriage valid. However, where the civil marriage was concluded 
before 1 December 1988, the customary marriage is automatically dissolved and the civil marriage valid.

Practitioners and any interested party should obtain affidavits from spouses to establish whether any customary marriage was concluded prior to the conclusion of the civil marriage, and not merely rely on the marriage certificate presented to them.

\section{Consequences of void marriages}

The aforegoing is a synoptic account of the occurrences and consequences of dual marriages. There is, however, more to it than meets the eye.

Before we proceed to discuss some possible implications we wish to state that it may have wide-ranging consequences for many people. According to Statistics SA (Statistical Release PO 307 Marriage and Divorce (2009)) 120,643 persons said that they were married by customary law from 2003 to 2009. The vast scope of potential conflicts is further high-lighted by the fact that in the 2001 Census 3,127,126 people said they were married by customary law of which 31,383 were polygynous marriages. The Recognition of Customary Marriages Act 120 of 1998 brought about legal certainty to a large extent, but its application gave rise to a number of legal issues. Many of the issues obviously do not land in court, because people take some things for granted and many don't have the insight nor financial means to enforce their legal rights in a court.

We must commence our discussion by saying that since colonists usurped power in South Africa customary marriages were regarded as "unions". The view was largely based on their interpretation of Christian doctrine that a marriage was a union between one woman and man for life. Hahlo and Kahn (The Union of South Africa: The Development of its Laws and Constitution (1960) 337) expressed the prevailing view as follows:

"The early liberal attitude by which at least certain of the courts were prepared to recognise the validity of a customary union which was de facto monogamous changed by the turn of the nineteenth century. Ostensibly, customary unions within the state were denied recognition for the same reason that recognition was being denied similar unions celebrated outside the country: they were of a polygynous nature, and it was of no avail to show that in fact neither spouse married another person, for their union was celebrated under tenets permitting the taking of further spouses during its existence which stamped it with the stigma of polygamy."

In terms of section 2(1) of the Recognition of Customary Marriages Act 120 of 1998, (s 3 of the Act) "a marriage which is valid at customary law and existing at the commencement of this Act is for all purposes recognised as a marriage". All customary marriages remain in force until dissolved by a competent court. In terms of section 8(1) of the Recognition of Customary Marriages Act -

"A customary marriage may only be dissolved by a court of divorce on the ground of the irretrievable breakdown of the marriage." 
Our question is whether the nullification of the civil marriage revives the customary marriage or marriages and all that has been done under them, lock stock and barrel. What is more, there may be a period when one or both parties were under the impression that their customary marriage was no longer in existence. Some married by civil rites and purchased property jointly with their "new'"spouse.

\section{Proof of existence of a customary marriage}

In this regard it must be borne in mind that the conclusion of a customary marriage is not a once-off legal act. Dissolution was no single legal event either. It went hand in hand with negotiations about the return of lobolo. But a person who wants to marry in terms of common law must prove that he or she is not married by customary law.

Here we must add that the most common dispute in the post-recognition phase is one of the parties denying the existence of a customary marriage. There are hard and fast requirements for marriages entered into after the Act came into operation (s 3 of the Act), but no statutory requirement for prior marriages. However, the most crucial requirement for all customary marriages is section $3(1(b))$ of the Act providing that the "the marriage must be negotiated and entered into or celebrated in accordance with customary law". This is what may be termed a "socio"-legal requirement that may be manipulated by a party to prove that he or she is married or not, depending on the most lucrative option. For instance, an agreement to pay lobolo and payment or part-payment is in our view an essential requirement for the validity of a customary marriage, yet the negotiation, the agreement and payment or part-payment may differ from case to case.

The question whether lobolo is payable, and if so, to whom and how much, is particularly problematic. Another question that may be raised is whether the void civil marriage may simply be regarded as having existed in a vacuum. What will the position be of obligations incurred by the parties, under the impression that they were married, say, in community of property?

What is the status of children born from such marriage?

\section{$5 \quad$ Putative marriages}

The patrimonial consequences and the status of the children may be resolved on the basis of the civil marriage having been a putative marriage. We cannot say how this would find application in practice. The main requirement for the existence of a putative marriage is that one or both parties must, in good faith, be unaware of the defect which renders their marriage void.

For present purposes it is not necessary to discuss in detail the requirements and consequences of putative marriages. We summarize our view that if a civil marriage is declared void ab initio some of the consequences flowing from a valid civil marriage may ensue; there may be patrimonial consequences, but we are particularly interested in the fact that "according to common-law authors, children born from a putative marriage 
are legitimate (Skelton, Carnelley, Human, Robinson and Smith Family Law in South Africa (2010) 55). That is laudable, but our concern is that the parties cannot simply assume that their marriage was a putative one. Nor can a string of other ensuing consequences be based on an assumption by the parties that their marriage is a putative one. Nor would the children ipso facto succeed to the estates of the putative parents. A judicial directive that the marriage is a putative one is surely required.

According to Skelton et al (Family Law in South Africa 55) "A practice developed that when parties approached a court to confirm a putative marriage null and void, they simultaneously applied for a declaration that children born from the marriage are legitimate".

\section{Succession}

When the legislature enacted the Reform of Customary Law of Succession and Regulation of Related Matters Act 11 of 2009 it enacted a savings provision as follows:

Section 7 provides that, in the event of the death of a husband who has entered into a civil marriage before 2 December 1988 with a woman other than the customary law spouse, the customary law spouse and the issue of the customary marriage must inherit on a par with the civil marriage widow and the issue from that marriage.

The date 2 December 1988 was the turning point. From that date a married man by customary law could not enter into a civil marriage with another woman. All such marriages are void ab initio.

The woman could marry another man in which event she could be his heir as well.

Likewise she could reap the benefits of being a "survivor" of a second marriage on the strength of being a survivor in terms of the definition of survivor as defined in section 1 of the Maintenance of Surviving Spouses Act (27 of 1990; and The Schedule of Amendment of Laws, s 8 of Act 11 of 2009).

Thus "discarded wives" enjoy ample protection.

There is lastly the position that a man who is the husband in a polygynous marriage might have married one of them by civil rites. This is not farfetched. In our involvement with the administration and study of customary law we have come across such cases. In terms of section 10(1) of the Recognition Act it is no longer possible because partners in a customary marriage may enter into a civil marriage only with each other, but such cases did occur. In terms of current law such other marriages are void.

\section{$7 \quad$ Plural marriages in Transkei}

Section 3(1) of the Transkei Marriage Act 21 of 1978 provided that no male person is prohibited - 
- during the subsistence of a customary marriage to contract a civil marriage with any female person; provided that the civil marriage was out of community of property;

- during the subsistence of a civil marriage out of community of property to contract a customary marriage (s 3(1) of Act 21 of 1978).

The Transkei Marriage Act came into operation on 12 February 1979 and section 3(1) was repealed by section 13 of the Recognition of Customary Marriages Act 120 of 1998 with effect from the date when the latter Act commenced on 15 November 2000. Marriages entered into between those two dates could therefore not be incompatible to the extent that one or the other may be declared void.

Such marriages may be few and far between, but the said provisions of the Transkei Act applied for some 22 years. There may therefore be some such marriages. The legal basis for their co-existence would be section 15(a) of the Justice Laws Rationalisation Act (18 of 1996). In terms of section 15(a), read with Schedule II, all laws of the former Republic of Transkei and anything done under them remain in force with the exception of sections 42 of 50 that were repealed. The Transkei Marriage Act as a whole has in fact not yet been repealed. Civil and customary marriage may therefore still be concluded in terms of that Act.

\section{Bigamy}

Since both marriages have the same legal status, the question arises whether in certain circumstances a party to a customary or civil marriage who enters into another marriage either way does not commit the crime of bigamy.

The situation is discussed in great detail by Bakker ("Bestaanbaarheid van Bigamie as Misdryf in 'n Kultureel Heterogene Samelewing" 2006 THRHR 64-78).

Suffice it for us to recapitulate Bakker's submission. Before the recognition of customary marriages a polygynous marriage did not qualify as a second marriage, because - to say the obvious - it was not a marriage. Although customary marriages are now marriages for all purposes, they are potentially polygynous and can consequently not be regarded as a second marriage for purposes of bigamy. However, if one of the marriages is a civil marriage it may constitute bigamy, because the ratio for the offence is to maintain the sanctity of monogamous marriages (par 2.2.2). Moreover, mens rea is an element of the crime. In most, if not all, polygamous marriages the persons concerned have no intention to do wrong. The religious foundation of monogamy is meaningless.

Bakker concludes by saying that the role of criminal law in a heterogeneous society is not to enforce the ideology of one part of the community. The crime of bigamy should therefore be decriminalized (Bakker 2006 THRHR 78). We agree. 


\section{$9 \quad$ Lobolo}

This is defined in section 1 of the Recognition of Customary Marriages Act as follows: "the property in cash or in kind, whether known as lobolo, bogadi, bohali, xuma, lumalo, thaka, ikhazi, magadi, emabheka or by any other name, which a prospective husband or the head of his family undertakes to give to the head of the prospective wife's family, in consideration of a customary marriage".

Although this definition may imply that lobolo is given only in respect of a customary marriage, in practice it is also given in anticipation of civil marriages. It has been indicated that no self-respecting African woman would regard herself as properly married without lobolo being given for her hand in marriage (see par 4.3.2.7 of the SA Law Commission Report on Customary Marriages (1998)).

It is evident from the definition that the parties to this agreement are the prospective husband or his family head, and the family head of the prospective wife. In the case of breach, the lobolo agreement may be enforced by means of court process.

The Recognition of Customary Marriages Act does not provide that lobolo is a requirement for a customary marriage, but we assume that it is because in terms of section $3(1)$ (b) of the Act "the marriage must be negotiated and entered into or celebrated in accordance with customary law". A customary marriage without lobolo is unconceivable.

Normally at the dissolution of the marriage due to fault on the part of his wife, lobolo is returned to the husband. Where the husband was to blame for the termination of the marriage, at least a portion of the lobolo is returnable to mark the dissolution. Where children were born during the marriage, lobolo is normally not returnable. The amount to be returned depends on various factors, for example, the number of children born, and the duration of the marriage (Bekker et al Introduction to Legal Pluralism in South Africa (2006) 47-48). Where a person wishes that lobolo be returned to him, the lobolo holder has to be cited as a party to the divorce proceedings so that an order may be obtained against him or her. If this was not done, the lobolo holder may be sued for such return after the dissolution of the marriage (Bekker et al Introduction to Legal Pluralism in South Africa 48). We submit that the lobolo holder may also be sued for return of the lobolo on a customary marriage being declared void. The same would apply in the event of a civil marriage being declared void.

\section{Polygyny}

The right of existence of polygyny is widely debated (Ruppel (ed) Women and Customs in Namibia: Cultural Practice Versus Gender Equality (2008) produced, for instance, a series of essays that highlight the different aspects of what might be termed the "problem" of cultural practice vis-a-vis gender equality). These marriages are in one way or another practised and recognized in different countries all over the globe. A discussion would take us too far afield, because it would require an account of the foundation, the 
practice and the consequences. We confine ourselves to a few South African views:

Dlamini ("The Role of Customary Law in Meeting Social Needs" 1991 Acta Juridica 77-78) declared emphatically:

"Although the incidence of polygamy may be decreasing for various reasons, it still has a role to play, not only for rural, non-literate people, but also for the educated. Polygyny may be a compromise between a happy marriage and divorce.

In an imperfect world it would be unwise to abolish this institution in favour of an ideal which even western society has not attained. The escalating divorce rate, not only in South Africa but worldwide, is a damning indictment against a society that claims to be civilized. The effect of this on children is traumatic and destructive."

$\mathrm{He}$ is not a lone voice in the wilderness. Maithufi and Moloi ("The Need for the Protection of Rights of Partners to Invalid Marriage Relationships. A Revisit of the 'Discarded Spouse' Debate" 2005 De Jure 152-153) expressed the same view from another perspective:

"It is therefore recommended that the South African marriage law be reformed to make it possible for the simultaneous existence of civil and customary marriages. This would enable a man already married by civil or customary rites to contract another marriage, be it civil or customary rites, with another woman during the subsistence of the first marriage. To continue regarding a civil marriage as a "union of one man and one woman to the exclusion of all others ..." is, in our opinion, not the best approach in the light of the existence of diverse cultural practices in South Africa. Similarly, to make it impossible for these marriages to exist side by side is tantamount to disregarding the many legal problems faced by parties to these relationships."

A third South African author, Mswela ("Cultural Practices and HIV in South Africa: A Legal Perspective" 200912 PER 20094 182/360) feels that polygynous marriages contribute towards the spread of HIV. This is what she says:

"The wives and sexual partners involved in polygamous marriages have little or no control over the sexual behaviour of other members within their family circle. The fear of being infected has led some women to oppose polygyny on the basis that it places them at a high risk not only of contracting HIV, but also of contracting a variety of other sexually transmitted diseases. Women across Africa have begun asking if a man really has a right to have more than one wife in the context of the HIV AIDS pandemic. In Swaziland, where almost forty percent of the population is HIV-positive, protest against polygyny is at its peak. The king of Swaziland has more than nine wives and traditionally chooses a new bride each year."

In our view the author's submission is unsound. She equates polygyny with immorality. It is unfair, we think, to depict polygyny as an immoral lifestyle. The roots and practice of present-day immorality (a world-wide phenomenon) cannot be lain at the door of polygyny. In fairness we must add that the author deals with a vast range of cultural practices that might lead to the spread of the virus. The prime reason for polygyny is not an accumulation of sexual partners. 
Polygyny has in any event dwindled to negligible proportions. But there have been and there still are polygynous marriages. In view of the current legal consequences, as sketched in outline above, polygyny will lead to legal conundrums for years to come. An example to point is that in terms of section 7(6) of the Recognition of Customary Marriages Act 120 of 1998:

"A husband in a customary marriage who wishes to enter into a further customary marriage with another woman after commencement of this Act must make an application to the court to approve a written contract which will regulate the future matrimonial property of his marriage."

In the case of Nqwenyama $v$ Mayelane (474/11 [2012] ZACSA 94) the Court held that section 7(6) of the Recognition Act is not a requirement for the validity of a subsequent customary marriage, but only meant to determine and regulate the proprietary consequences of such a marriage. The court did not say what the patrimonial consequences of such marriage are nor what effect these might have on previous marriages.

\section{Conclusion}

Courts normally don't adjudicate in matters that are not raised in pleadings. The equal status of customary and civil marriages and the possibility of one of them being declared void should in our view oblige them to consider the possible consequences. It must be borne in mind that for many years the customary law of marriage was a non-specialized system of law - for the most part unwritten and without clear-cut immutable rules. The Recognition of Customary Marriages Act has in one swoop converted it into a specialized system with rigid statutory rules, particularly enacting requirements for validity, patrimonial consequences and dissolution. We think it has caught married persons and persons who propose to marry by customary law on the wrong foot. From our experience we may safely say that in many cases people will in any event "do their own thing". But some may have to pay a price to resolve the consequences of non-compliance.

Allen West

Chief, Deeds Training, Pretoria and

JC Bekker

University of Pretoria 